\title{
THE EFFECT OF RENAL DENERVATION ON THE LEVEL OF ARTERIAL BLOOD PRESSURE AND RENAL FUNCTION IN ESSENTIAL HYPERTENSION
}

\author{
BY IRVINE H. PAGE AND GEORGE J. HEUER \\ (From the Hospital of the Rockefeller Institute for Medical Research, New York, and \\ the Department of Surgery, New York Hospital, New York)
}

(Received for publication September 12, 1934)

Hypertension is one of the most frequent complications of renal disease, both acute and chronic. The fact that in nephritis renal influences, nervous or other, apparently produce hypertension suggests the possibility that the unknown cause of essential hypertension may lie in nervous impulses from the kidney, even though the kidneys themselves appear to be entirely normal at the onset of the hypertension.

We have accordingly performed bilateral renal denervation on a patient with essential hypertension uncomplicated by detectable renal involvement, and with but slight evidence of anatomical changes in the circulatory system. Because the hypertension was still in its initial stage, without organic damage, it appeared possible that therapeutic lowering of the blood pressure might occur.

\section{History of the patient}

This 25-year old girl complained that she became easily fatigued and was extremely nervous. Cardiac disease had been found in her father and two sisters. At the age of 13 she had chorea with involvement of her heart. Six years later a tonsillectomy was performed because of swelling and pain in certain of her joints. Low grade hypertension was found during an examination before the operation. Since then she had not been troubled by symptoms of rheumatic fever, but hypertension had continued and became pro- gressively more marked. In the past few years she had noticed that she blushed spontaneously, and that she cried for no apparent reason. She also had palpitations, her mouth became dry and she often had attacks of trembling. During the past three years, about two or three times a year, she had had mild fits suggestive of epilepsy. Until recently she had had many severe headaches, especially pronounced a few days before her menstrual period.

Physical examination. The patient was a well developed but thin girl with a markedly masculine build and hair distribution. There was a pronounced blotchy blush over the face, neck and upper thorax. Her hands and feet were cold and moist with perspiration.

Examination of the fundus revealed that the nerve head was of a deep pinkish color without papilledema. The arterioles were slightly constricted and definitely tortuous. Perivasculitis was not evident. The veins were tortuous and dilated and arteriovenous constriction was seen. There was no exudate or hemorrhage in the retina. Vision was good in all sectors.

There was marked systolic pulsation in the jugular notch. The thyroid gland was normal to palpation. The beating of the heart caused a marked thrust and the rate was rapid but regular. The heart appeared very slightly enlarged to the left. The first sound at the apex was snapping in

TABLE I

Lipid of plasma from fasting patient

\begin{tabular}{|c|c|c|c|c|c|c|c|c|c|c|}
\hline & \multirow{2}{*}{$\begin{array}{l}\text { Total } \\
\text { lipid } \\
\text { carbon }\end{array}$} & \multicolumn{3}{|c|}{ Cholesterol } & \multirow{2}{*}{$\begin{array}{c}\text { Lipid } \\
\text { amino } \\
\text { nitrogen }\end{array}$} & \multirow{2}{*}{$\begin{array}{c}\text { Total } \\
\text { lipid } \\
\text { nitrogen }\end{array}$} & \multirow{2}{*}{$\begin{array}{l}\text { Lipid } \\
\text { phos- } \\
\text { phorus }\end{array}$} & \multirow{2}{*}{$\begin{array}{l}\text { Total } \\
\text { fat }\end{array}$} & \multirow{2}{*}{$\begin{array}{l}\text { "Cephalin" } \\
\text { calculated } \\
\text { from NH, } \\
\text { nitrogen }\end{array}$} & \multirow{2}{*}{$\begin{array}{c}\text { Total } \\
\text { phosphatide } \\
\text { calculated } \\
\text { from } \\
\text { phosphorus }\end{array}$} \\
\hline & & Total & Free & Ester & & & & & & \\
\hline $\begin{array}{l}\text { Patient. . . . . . . } \\
\text { Average normal }\end{array}$ & $\begin{array}{c}\text { mgm. per } \\
100 \text { cc. } \\
439 \\
528\end{array}$ & $\begin{array}{c}\text { mgm. per } \\
100 \text { cc. } \\
241 \\
212\end{array}$ & $\begin{array}{c}\text { mgm. per } \\
100 \text { cc. } \\
77 \\
83\end{array}$ & $\begin{array}{c}\text { mgm. per } \\
100 \text { cc. } \\
164 \\
129\end{array}$ & $\begin{array}{c}\text { mgm. per } \\
100 \text { cc. } \\
2.5 \\
3.1\end{array}$ & $\begin{array}{c}\text { mgm. per } \\
100 \mathrm{cc} . \\
8.9 \\
9.7\end{array}$ & $\begin{array}{c}\text { mgm. per } \\
100 \text { cc. } \\
5.7 \\
6.3\end{array}$ & $\begin{array}{c}\text { mgm. per } \\
100 \text { cc. } \\
570 \\
664\end{array}$ & $\begin{array}{c}\text { mgm. per } \\
100 \text { cc. } \\
132 \\
174\end{array}$ & $\begin{array}{c}\text { mgm. per } \\
100 \text { cc. } \\
134 \\
147\end{array}$ \\
\hline
\end{tabular}


character associated with a soft presystolic murmur and a short diastolic whiff. $A_{2}$ and $P_{2}$ were slightly accentuated. The peripheral blood vessels were moderately thickened but not tortuous. The blood pressure was $208 / 140 \mathrm{~mm}$. Hg.

The abdomen was scaphoid. Both kidneys were palpable but not enlarged. Tremor was not observed in the fingers when the arms were outstretched. The superficial and deep reflexes were equal on both sides and hyperactive. There was a slight bilateral ankle clonus.

Laboratory examination. Renal function, as measured by the urea clearance test of M $\phi$ ller, McIntosh and Van Slyke (1), was 91.5 per cent of average normal. The Addis sediment test showed that no significant number of red blood cells or casts were being excreted in the urine, that the specific gravity was 1.030 , and that the protein excreted was not greater than 0.02 gram in 12 hours. Sugar was not found in the urine. The basal metabolic rate was +5 . The hemoglobin was 20.5 volumes per cent oxygen capacity. The white blood cells numbered 8000 and the Kline test was negative.

Estimation of the plasma lipids by the method of Kirk, Page, and Van Slyke (2) showed that they were all within normal limits. (For normal values see Page, Kirk, and Van Slyke (3).)

$\mathrm{X}$-ray examination of the heart showed that it was but little enlarged and of normal shape. The measurements were as follows: M.L. $=8.7 \mathrm{~cm}$. M.R. $=3.9 \mathrm{~cm}$. Internal diameter of thoracic cage $=22 \mathrm{~cm}$. The peripheral vessels showed no calcification and the sella turcica was normal. The electrocardiogram exhibited the following characteristics: $\mathrm{T}$ waves +++ ; conduction time $0.16 ; \mathrm{P}_{1}$ and $\mathrm{P}_{3}$ split; normal rhythm.

Course. For convenience the laboratory and certain of the clinical observations are plotted in Figure 1. The points on the blood pressure record represent average blood pressure levels.

The blood pressure, taken daily at 9:30 a.m. with the patient strictly confined to bed at all times, showed little tendency to fall. Nor did a course of sodium thiocyanate therapy (up to grains iv O.D.) have any marked effect.

The kidneys were entirely normal in so far as could be ascertained by clinical examination. Renal function was normal as measured by the power of the kidneys to remove urea from the

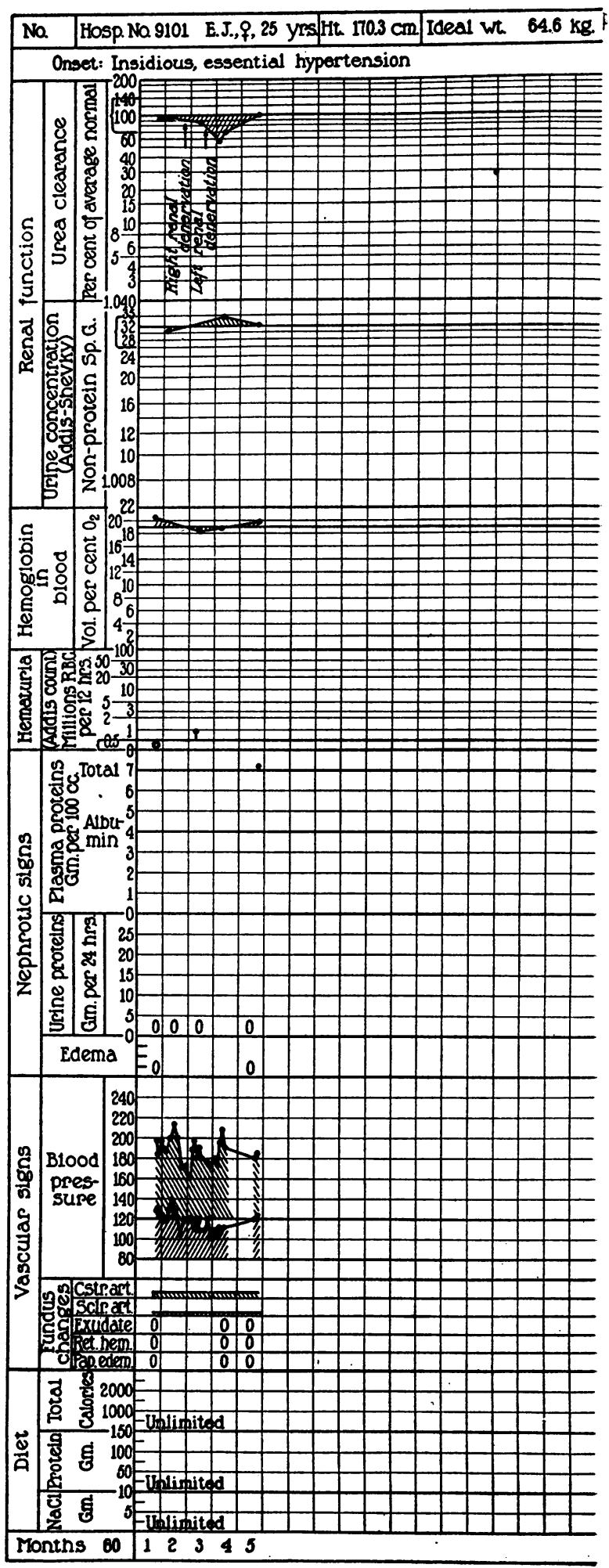

Fig. 1. 
blood and by ability to concentrate the urine. No appreciable quantity of protein or red blood cells was excreted into the urine, nor was anemia present.

About one month after admission, since the patient did not appear to be improving, denervation of the right kidney was performed. This operation will be described, as performed by us, in another publication concerned with the results of denervation in patients suffering from nephritis. The operation went smoothly and recovery was uneventful. The kidney was found to be normal in appearance. Sections of muscle removed from the lumbar muscles showed, according to Dr. C. $P$. Rhoads, very little intimal change.

Following operation no change in renal function or blood pressure level was observed. About one month later the left kidney was denervated. Again no significant change occurred in the renal function measured by the urea clearance test or the ability to concentrate. A slight fall occurred in the average diastolic pressure. This was not considered significant in view of the fact that the patient had been subjected to two major operations. Shortly after operation there was a slight increase above normal in the number of red blood cells excreted in the urine, but the hematuria quickly subsided. No change was observed in the eyegrounds as the result of the operations. The hemoglobin also did not change significantly.

An attempt was made by Dr. O. Lowsley to catheterize the ureters after the first operation. The bladder was found to be normal, but the catheters could not be inserted more than five centimeters into the ureters presumably because of spasm. It is interesting to note that on the denervated side the patient felt no pain following cystoscopy. Conversely, on the innervated side the pains were crampy and intense.

The patient felt as well after the two operations as before. No symptoms such as polyuria, nocturia or urgency appeared. However, it cannot be said that she was improved.

\section{DISCUSSION}

Since the level of arterial blood pressure did not fall significantly following bilateral denervation of the kidneys, it was concluded that in this patient suffering from severe essential hypertension nervous impulses originating in the kidneys did not share in the maintenance, and probably therefore not in the genesis of the hypertension. The results in this typical case were so decisive that they make it appear doubtful that the kidneys play any rôle, as a general thing, in the genesis of essential hypertension.

Renal denervation was first performed in man by Papin and Ambard (4) for relief of pain. Quinby (5) (1916), Milliken and Carr (6) (1925) and Caldwell, Marx and Rowntree (7) (1931) have presented comprehensive reviews of the literature. Patients suffering from essential hypertension have not heretofore been subjected to renal denervation.

Evidently bilateral denervation is not an operation which jeopardizes renal function. Neither the urea clearance nor the ability to concentrate were impaired. Polyuria and fixation of specific gravity, shown to occur by Quinby (5) and Marshall and Kolls (8) in dogs following denervation, were not observed in our patient.

\section{SUM MARY}

1. Bilateral renal denervation, in a patient suffering from severe essential hypertension, did not change the level of arterial blood pressure, hence our results give no ground for expecting that denervation in cases of essential hypertension is of therapeutic value.

2. No ill effects, either renal or extrarenal, were observed after the denervation. Renal efficiency, as measured by the urea clearance test and the ability of the kidneys to concentrate, was normal before operation and remained unchanged after denervation.

3. Our results do not support the hypothesis that essential hypertension originates in whole or in part in the nervous mechanism of the kidneys.

\section{BIBLIOGRAPHY}

1. M $\phi 1$ ler, E., McIntosh, J. F., and Van Slyke, D. D., Studies of urea excretion. II. Relationship between urine volume and the rate of urea excretion by normal adults. J. Clin. Invest., 1928, 6, 427.

2. Kirk, E., Page, I. H., and Van Slyke, D. D., Gasometric microdetermination of lipids in plasma, blood cells and tissue. J. Biol. Chem., 1934, 106, 203. 
3. Page, I. H., Kirk, E., and Van Slyke, D. D., Plasma lipids in normal persons and in patients suffering from essential hypertension, malignant hypertension and Bright's disease. (In press.)

4. Papin, E., and Ambard, L., Resection of the nerves of the kidney for nephralgia and small hydronephroses. J. Urol., 1924, 11, 337.

5. Quinby, W. C., The function of the kidney when deprived of its nerves. J. Exper. Med., 1916, 23, 535.

6. Milliken, L. F., and Karr, W. G., The influence of the nerves on kidney function in relation to the prob- lem of renal sympathectomy. J. Urol., 1925, 13, 1. 7. Caldwell, J. M., Jr., Marx, H., and Rowntree, L. G., Renal function after bilateral denervation of the kidneys in normal dogs. J. Urol., 1931, 25, 351.

8. Marshall, E. K., Jr., and Kolls, A. C., Studies in the nervous control of the kidney in relation to diuresis and urinary secretion. I. The effect of unilateral excision of the adrenal, section of the splanchnic nerve and section of the renal nerves on the secretion of the kidney. Am. J. Physiol., 1919-20, 49, 302. 